5. Kiyashchenko N.I. Mass culture and mass art as a global problem of the XXI century / Philosophy and society. Vol. 4 (33) Massovaya kultura i massovoye iskusstvo kak global'naya problema XXI veka / Filosofiya i obshchestvo. Vol.3(33)/ 2003. (In Russian)

6. Kurysheva T. A. Musical journalism and music criticism: a study guide for universities. Muzykalnaya zhurnalistika i muzykal'naya kritika. Vlados-press Publ., 2007, 295 p. (In Russian)

7. Matskevich. Yu.V. The definition of the concept of " piece of art "and the designation of the criteria for its evaluation". Opredeleniye ponyatiya "proizvedeniye iskusstva» $i$ oboznachenii kriteriyev yego otsenki. (In Russian)

8. Merezhkovsky, D. S. On the decline reasons and the new trends of modern Russian literature / Eternal satellites. Portraits from world literature. O prichinakh upadka $i$ o novykh techeniyakh sovremennoy russkoy literatury / Vechnyye sputniki. Portrety iz vsemirnoy literatury. St. Petersburg, Science Publ, 2007, pp. 428-502. (In Russian)

9. Mikhalchenko B.S. Problems of literary criticism: a theory of literature. Problemy literaturovedeniya: teoriya literatury. (In Russian)

10. Stolovich L.N. The nature of aesthetic value. Priroda esteticheskoy tsennosti. Moscow, 1972, 272 p. (In Russian)

11. Sorokina N. Art and money. Iskusstvo i dengi. Moscow, AST Publ., 2016, 272 p. (In Russian)

12. Yakovleva A.M. Kitsch and Parakich: The Birth of Art from the Prose of Life // The Art Life of Russia in the 1970s as a Systemic Whole. Kich i parakich: Rozhdeniye iskusstva iz prozy zhizni // Khudozhestvennaya zhizn' Rossii 1970-kh godov kak sistemnoye tseloye. St. Petersburg: Aletheia Publ., 2001, pp. 252-263. (In Russian)

13. Rating of the world countries in terms of education. Humanitarian Encyclopedia: Research [Electronic Resource] // Center for Humanitarian Technologies, 2006-2020 (latest revision: 01/17/2020). URL: https://gtmarket.ru/ratings/education-index/education-index-info

UDC

doi: 10.31650/2519-4208-2020-20-306-312

\title{
METHODOLOGY FOR DETERMINING MATURITY OF COMPOSITIONAL SKILLS IN ARCHITECTURE STUDENTS
}

Grigoryeva V. B., Ph. D. in Education, Assistant Professor, Head of the Sub-Department of Drawing, Painting and Architectural Graphics

Tel. +380980481617

Spodeniuk S. I. Senior Teacher at the Sub-Department of Drawing, Painting and Architectural Graphics

Tel. +380961847062

Poronik E. G. Senior Teacher at the Sub-Department of Drawing, Painting and Architectural Graphics

Tel. +380506750875

Odessa State Academy of Civil Engineering and Architecture

Abstract. In methodological literature an architect's culture of depiction is artificially divided into two components: artistic component and design component. However, contemporary studies pay not enough attention to development of compositional thinking in students as an important factor for uniting the above components.

Compositional thinking manifests itself in compositional activity, which is a specific quality of cognitive activity in art. Compositional activity involves both intellectual (acts of 
thinking) and practical (acts of depiction) acts. Systemic approach to development of acts of thinking and practical acts in students during drawing classes shapes up a necessary level of compositional activity for solution of artistic and design tasks in their future occupation.

The paper contains an analysis of certain features of development of compositional skills in architecture students at the final stage of depiction skills training.

Based on outcomes of the first stage of the summative assessment, we have identified criteria of compositional skills and three levels of maturity of such skills in architecture students, as a result of the suggested methodology.

The following criteria of compositional skills have been identified based on results of analysis of academic assignments completed by students and structure of compositional thinking, namely: perception and figurative image of life (space), structural organization of the concept, use of appropriate depiction tools of composition. Three levels of maturity of compositional skills in the $4^{\text {th }}$ year students have been identified based on those criteria: high, medium and low.

High level was characterized by artistic vision of life and future composition, constant apperception (perception, recognition), emotional responsiveness, in-depth knowledge of key theoretical and practical compositional patterns, adequate use of depiction tools. Grades "excellent" and "good" (9.6\%).

Medium level of maturity of compositional skills manifested itself in unsteady apperception, indifferent attitude to the task, uncertainty when selecting compositional techniques and tools, use of templates. Grade "satisfactory" (66.1\%).

Low level was characterized by total lack of interest to the task, ignorance concerning elementary patterns for creation of composition, apathy and helplessness. Grade "unsatisfactory" $(24.3 \%)$.

Conclusions and Future Scope of Research. Study of curriculum-based and methodological materials for institutions of higher architectural education, questionnaire survey and completion of exercises by students revealed a gap between theoretical knowledge and practical compositional activity, in the process of which no attention was paid to acquisition of a consistent system of scientific knowledge and to development of flexible professional skills and abilities in students. At the first stage of the summative assessment we have also identified dependence between systemic development of the students' mental actions and the overall process of development of compositional activity. Development of mental actions of various kinds determines nature and level of compositional thinking, which in its turn provides for professional training of students and is characterized by independence, originality, associativity, visualization, observation skills, visual memory and imagination.

In the course of the assessment we have identified criteria and levels of maturity of compositional skills in the $4^{\text {th }}$ year architecture students.

Based on summarized data, we have identified reasons for insufficient level of maturity of compositional thinking skills in architecture students. Among key reasons one should mention focus of artistic courses taught in an institute of architecture and art on practical activity only, total absence of lectures in the theory of composition, drawing, painting in the curriculum for architecture students, lack of scientific approach to development of compositional skills.

We believe that directions for research of this problem include identification of teaching environment and creation of a didactic model for development of compositional skills in architecture students, development of a system of theoretical knowledge and graphic exercises to learn tools for depiction of space in a plane.

Key words: architectural education, compositional thinking, compositional activity, compositional skills, criteria and levels of maturity of compositional skills. 


\section{МЕТОДИКА ВИЗНАЧЕННЯ СФОРМОВАНОСТІ НАВИЧОК КОМПОЗИЦЙНОЇ ДІЯЛЬНОСТІ СТУДЕНТІВ-АРХІТЕКТОРІВ}

Григор’єва В. Б., кандидат педагогічних наук, доцент, завідуюча кафедри рисунка, живопису та архітектурної графіки

Тел. +380980481617

Споденюк С. І., старший викладач кафедри рисунка, живопису та архітектурної графіки Тел.+380961847062

Поронік Э. Г., старший викладач кафедри рисунка, живопису та архітектурної графіки Тел. +380506750875

Одеська державна академія будівниитва та архітектури

Анотація: В методичній літературі існує штучне розділення образотворчої культури архітектора на дві складові: художню та проектну. Однак у сучасних дослідженнях приділяється недостатньо уваги розвитку композиційного мислення студентів як важливого чинника їх об’єднання.

Композиційне мислення виявляється в композиційній діяльності, що є специфічною якістю пізнавальної діяльності в мистецтві. Композиційна діяльність передбачає як інтелектуальні (розумові операції), так і практичні (образотворчі) дії. Системний підхід до розвитку розумових та практичних дій студентів на заняттях 3 дисципліни «Рисунок» формує необхідний рівень композиційної діяльності для вирішення художніх та практичних задач у майбутній професії.

В статті проаналізовані деякі особливості формування навичок композиційної діяльності студентів-архітекторів на завершальному етапі вивчення образотворчої грамоти.

За результатами першого етапу констатуючого експерименту були визначені критерії навичок композиційної діяльності та три рівні сформованості цих навичок у студентів-архітекторів в результаті розробленої методики.

Ключові слюва: архітектурна освіта, композиційне мислення, композиційна діяльність, навичка композиційної діяльності, критерії та рівні сформованості композиційної діяльності.

\section{МЕТОДИКА ОПРЕДЕЛЕНИЯ СФОРМИРОВАННОСТИ НАВЫКОВ КОМПОЗИЦИОННОЙ ДЕЯТЕЛЬНОСТИ СТУДЕНТОВ-АРХИТЕКТОРОВ}

Григорьева В. Б., кандидат педагогических наук, доцент, заведующая кафедрой рисунка, живописи и архитектурной графики

Тел. +380980481617

Споденюк С. И., старший преподаватель кафедры рисунка, живописи и архитектурной графики

Тел.+380961847062

Пороник Э. Г. старший преподаватель кафедры рисунка, живописи и архитектурной графики

Тел. +380506750875

Одесская государственная академия строительства и архитектуры.

Анотация: В методической литературе существует искусственное разделение изобразительной культуры архитектора на две составляющие: художественную и проектную. Однако в современных исследованиях уделяется недостаточно внимания развитию композиционного мышления студентов как важного фактора их объединения. 
Композиционное мышление проявляется в композиционной деятельности, что есть специфическим качеством познавательной деятельности в искусстве. Композиционная деятельность предполагает как интеллектуальные (мыслительные операции), так и практические (изобразительные) действия. Системный поход к развитию мыслительных и практических действий студентов на занятиях по дисциплине «Рисунок» формирует необходимый уровень композиционной деятельности для решения художественных и проектных задач в будущей профессии.

В статье проанализированы некоторые особенности формирования навыков композиционной деятельности студентов-архитекторов на завершающем этапе изучения изобразительной грамоты.

По результатам первого этапа констатирующего эксперимента были определены критерии навыков композиционной деятельности и три уровня сформированности этих навыков у студентов-архитекторов в результате предложенной методики.

Ключевые слова: архитектурное образование, композиционное мышление, композиционная деятельность, навык композиционной деятельности, критерии и уровни сформированности композиционной деятельности.

Problem Statement. Ukrainian national development strategy for the years 2012-2021 provides for raising a person of culture with a high level of national identity and a steady system of values motivating such person's creative activity. Change in style of the contemporary architect's professional thinking defines content and innovative nature of architectural education.

Problem of developing a professional approach in architects-to-be to study of composition of the real-life space and its depiction in a plane of a paper sheet remains uncovered. As of now, a perfect combination of professional trade and artistic visual thinking of the architect-to-be has not been found. In methodological literature manifestations of an architect's culture of depiction are artificially divided into two components. As follows from analysis of methodological literature in drawing for institutions of higher architectural education, teachers divide students' graphic work into two kinds: artistic and architectural drawing and design drawing.

Artistic and architectural drawing means a finished graphic work or a sketch of the future composition. Design drawing means a graphic search for an image of architectural space with solution of artistic and spatial structures of architectural environment with reference to plans, sections and facades.

Architectural education concept is studied in works by V. L. Baryshnikov, E. A. Kaidanovskaya, S. N. Karpova, Z. S. Nagaeva, V. A. Cherna, N. Li and other researchers and teachers. History and methodology of teaching architecture students drawing are analyzed in works by V. G. Lisovskiy, N. M. Moleva, E. M. Beliutin. Features of visual perception of a painting and formation of a visual image of architectural and canvas space are studied in works by N. N. Volkov, V. P. Zinchenko, P. A. Kuzin, B. G. Ananiev, B. R. Raushenbakh and other researchers. Basics of artistic compositional modelling and space-time modelling of architectural composition are studied in works by V. I. Iovlev, A. D. Kulikov, L. I. Sedova and other teachers. However, methodological literature contains no significant studies of development of compositional thinking in architects-to-be as an important factor for uniting two components of their culture of depiction.

This topic is included into the topic plan of Odessa State Academy of Civil Engineering and Architecture (UDC 378.147.11.7 - Improvement of Depiction Skills Training of Architecture Students by Means of Drawing, Painting, Sculpture, History of Arts and Architecture), state registration number $0117 \mathrm{U} 002171$. 
Object of Research - teaching drawing to architects-to-be.

Purpose of Research - on the basis of the first stage of the summative assessment to identify level of theoretical and graphic skills of the $4^{\text {th }}$ year architecture students in drawing.

Tasks of Research - to identify criteria and levels of maturity of compositional skills in architecture students.

Presentation of the Main Material. Professionalism in an architect's drawing depends on successful learning of skills for perception of urban space on the basis of a working drawing and compositional thinking skills when creating a holistic image in a plane; graphic space and shape modelling skills using depiction tools. For the purpose of academic process stimulation in that regard we should create new methods for development of skills in students for perception of space in existing depiction systems.

Creation of a system of special knowledge and practical skills in drawing is connected with graphic compositional activity and serves as a basis for development of compositional thinking in students.

Compositional thinking is a variety of artistic thinking. It manifests itself in such actions as comparison, generalization, classification, systematization, abstraction, specification. Compositional thinking is defined by three interconnected factors: perception of life (space), structural organization of the concept and depiction tools of a drawing. Compositional thinking process may be described as movement towards creation of the artistic whole, and it is represented as movement of visual thinking from isolated to holistic actions: structural organization of the concept, where components of life and image are interconnected.

Compositional thinking manifests itself in compositional activity, which is a specific quality of cognitive activity in art. Compositional activity involves both intellectual (acts of thinking) and practical (acts of depiction) acts. As a result of compositional activity, students feel an objective need to acquire compositional skills at an adequate level.

Theory of step-by-step development of skills enabled us to assume that a system of exercises for learning basic compositional laws in drawing might serve as an efficient tool for acquisition of knowledge, abilities and skills of compositional activity.

First stage of the summative assessment took place in drawing classes for the $4^{\text {th }}$ year architecture students of the Institute of Architecture and Art at Odessa State Academy of Civil Engineering and Architecture in the academic year 2018/2019 (total number of students: 78).

For this purpose we developed 3 variants of questions on general knowledge of the theory of composition in drawing and exercises with a varying degree of complexity of architectural compositions.

Results of the questionnaire survey supported the assumption that only a small group of those asked (18\%) studied the theory of composition and applied knowledge in practice on a regular basis, where only $3 \%$ of the students had an interest in studies with an outlook for their future occupation; $15 \%$ were those who studied because they had to pass tests in the subject. As a result, theoretical competence of the $4^{\text {th }}$ year students was very low: $35 \%$ of the total number of those asked could not name common laws of composition in drawing, their impact on perception of the plane (format), could not determine a difference between compositional techniques and tools, did not understand the effect of knowledge on practical work; $40 \%$ had incomplete knowledge and immature understanding of notions in composition and drawing; $7 \%$ of students refused to take part in questionnaire survey due to total lack of knowledge.

Practical exercises at this stage of the summative assessment were given in logical sequence of studying the architectural form and identified maturity of compositional skills in the $4^{\text {th }}$ year architecture students. 
For instance:

Exercise 1. Composition in a plane.

To create a composition with 4 geometric figures in A4 format in three relations (white, grey and black tones).

Purpose: to create a balanced composition in the format.

Material: pencils of varying hardness.

Exercise 2. Relief composition.

To create a composition with abstract spots (unlimited number) in A4 format.

Purpose: to create an illusory spatial composition in the format.

Material: pencils of varying hardness.

Exercise 3. Three-dimensional composition.

To create a composition of a still-life painting of household items from imagination in daylight in A4 format.

Purpose: to create a balanced composition of a still-life painting revealing spatial plans and dimensions in A4 format.

Material: pencils of varying hardness.

Exercise 4. Three-dimensional spatial composition.

Purpose: to create a stylized composition from imagination on the basis of a real-life urban motif in A4 format.

Material: pencils of varying hardness.

For completion of all practical exercises students were given 45 minutes.

Results of the exercises enabled us to make the following conclusions: most students (75\%) had no compositional skills, no knowledge of methodological sequence of the graphic work process, their initial concept remained unchanged; $25 \%$ of the students did not know basic notions for creation of a compositional form and worked by the method of trial and error.

\section{LITERATURE}

1. Bilhorodska O. E., Konshyna O. M., Kucherenko K. P. (2019). Zobrazhennia eksterieru vnutrishnioho zamknutoho prostoru yak odyn $\mathrm{z}$ etapiv formuvannia hudozhnio-hrafichnykh umin ta navychok studentiv-arkhitektoriv( na prykladi zobrazhennia "Odeskykh dvorykiv" [Depiction of Exterior of the Interior Closed Space as One of Stages of Development of Artistic and Graphic Abilities and Skills in Architecture Students (Depicting Odessa Courtyards as an Example).]. Zbornik nauchnyh trudov "Problemy teorii $i$ istorii arhitektury Ukrainy" Collection of Academic Papers "Problems of Theory and History of Ukrainian Architecture", (Issue No. 19.), (p.p 348-355 (specialized publication), ISSN 2519-128. [in Ukrainian].

2. Kaidanovska O. O. (2015). Teoretyko-metodychni osnovy obrazotvorchoi pidhotovky arkhitektoriv u vyshchykh navchalnych zakladakh. 13.00.04 [Theoretical and Methodological Principles of Depiction Skills Training of Architects in Institutions of Higher Education. 13.00.04.]. Synopsis of the thesis for a doctoral degree in education. Kyiv. [in Ukrainian].

3. Karpova S. N. (2017). Problema professionalnoi podgotovki budushchih arhitektorov v teorii I praktikr vysshego arhitekturmogo obrazovaniia [Problem of Professional Training of Architectsto-Be in Theory and Practice in Institutions of Higher Architectural Education ]. Naukovyi visnyk Pivdennoukrainskoho natsionalnoho pedahohychnoho universitetu imeni K.D. Ushinskoho: Zbirnyk naukovykh prats. Academic Bulletin of the South-Ukrainian National Pedagogical K. D. Ushinsky University: Collection of Academic Papers. (Issue No. 3 (116). (P. 36-39). Odessa [in Russian].

4. Kinash I. P. (2011).Yakist osvity yak rezultat, protses ta osvitnia systema [Quality of Education as a Result, Process and Educational System]. Naukovyi zbirnyk NLTU Ukrainy: zbirnyk naukovo-tekhnychnykh prats - Academic Bulletin of the National Forestry University of 
Ukraine: Collection of Papers in Science and Engineering. (Issue 21.5.), (P. 363-368.).Lviv: Editorial and Publishing Unit of the National Forestry University of Ukraine [in Ukrainian].

5. Nagaeva Z. S. (2014) Opyt, problemy, perspektivy arhitekturno-hudozhestvennogo obrazovaniia [Best Practices, Problems, Prospects of Education in Architecture and Arts]. Visnyk Donbaskoi natsionalnoi akademii budivnytstva ta arkhitektury. Problema arkhitektury I mistobuduvannia - Bulletin of Donbas National Academy of Civil Engineering and Architecture. Problem of Architecture and Urban Planning. (Issue 2014-2 (106). [in Russian].

6. B. S. Posatskyi (2011). Osnovy urbanistiky. Terytorialne ta prostorove proektuvannia: navch.posib[dlia studentiv baz. napriamu "Arkhitektura".] [Basics of Urban Studies. Territorial and Spatial Design: Textbook [for Students Majoring in Architecture]. Lviv: Polytechnika [in Ukrainian].

7. V. V. Tovbych \& M. V. Sysoilov (2007). Arkhitektura: mystetstvo ta nauka[tekst] [Architecture: Art and Science [text]. - (Vol. 1: Evolvement and Development of Architectural Processes and Phenomena.). Kyiv: Svidler [in Ukrainian].

УДК 72.03(460)

doi: $10.31650 / 2519-4208-2020-20-312-321$

\section{ИССЛЕДОВАНИЕ ГЕОМЕТРИИ В ТВОРЧЕСТВЕ АРХИТЕКТОРА АНТОНИО ГАУДИ}

Перпери А. А., канд. техн. наук, доцент, зав. кафедрой начертательной геометрии и инженерной графики

ORCID: 0000-0001-7112-6864

Яворская Н. М., старший преподаватель кафедры начертательной геометрии и инженерной графики

ORCID: 0000-0002-2790-2691

Яворский П. В., ассистент кафедры начертательной геометрии и инженерной графики ORCID: 0000-0003-4075-2058

Одесская государственная академия строительства и архитектурь

Аннотация: Исследуя творчество Антонио Гауди и его знание начертательной геометрии, которое развивает пространственное воображение, замечаем применение линий, фигур, объёмных геометрических образов в архитектурном творчестве. В раннем творчестве Антонио Гауди проектирует здания в мавританском стиле, используя геометрические формы и линии, подчеркивающие арабские мотивы в узорах. Так в доме Виссенти, выполненном в стиле модернизма, применил идею самоповторяющегося элемента простой формы в более сложную. Во фрагменте галереи городского парка Гуэль, являющего собой пример урбанистического стиля, Гауди использовал трансформацию одной поверхности в другую, при этом показывая плавность линий и точность построения поверхностей и не нарушая их закономерность. Антонио Гауди в практическом творчестве брал самоповторяющейся алгоритм, который складывался в пространстве в необходимую для его замысла форму. Гауди в совершенстве владел навыками и знаниями дисциплины, которая называется «начертательная геометрия». Развивая пространственное воображение, эта дисциплина предлагает нам всевозможные виды линий, геометрических фигур и объемных тел для воплощения идей мастеров архитектуры, одним из которых является Антонио Гауди.

Ключевые слова: геометрический образ, начертательная геометрия, образующая, кривые линии второго и третьего порядка, формообразование, пространственное воображение. 